\title{
Sorafenib tolerability in elderly patients with advanced renal cell carcinoma: results from a large pooled analysis
}

\author{
G Procopio*,1 , J Bellmunt ${ }^{2}$, J Dutcher ${ }^{3}$, S Bracarda ${ }^{4}, \mathrm{~J} \mathrm{Knox}^{5}$, A Brueckner $^{6}$, I Molnar ${ }^{7}$, B Escudier ${ }^{8}$ and \\ T E Hutson ${ }^{9}$
}

${ }^{1}$ Department of Medical Oncology 1, Fondazione IRCCS 'Istituto Nazionale Tumori', Milan, Italy; ${ }^{2}$ Department of Solid Tumor Oncology (Genitourinary and Gastrointestinal), University Hospital del Mar-IMIM, Barcelona, Spain; ${ }^{3}$ St Luke's Roosevelt Hospital Center, Beth Israel Medical Center, Continuum Cancer Centers, New York, NY, USA; ${ }^{4}$ Department of Medical Oncology, Ospedale San Donato-USL8, Arezzo, Italy; ${ }^{5}$ Department of Medical Oncology and Hematology, Princess Margaret Hospital, Toronto, ON, Canada; ${ }^{6}$ Bayer HealthCare, Leverkusen, Germany; ${ }^{7}$ Bayer HealthCare Pharmaceuticals Inc, Montville, NJ, USA; ${ }^{8}$ Department of Cancer Medicine, Institute of Gustave-Roussy, Villejuif, France and ${ }^{9}$ Texas Oncology at Baylor Charles A. Sammons Cancer Center, Dallas, TX, USA

Background: Elderly patients tend to be underrepresented in renal cell carcinoma (RCC) clinical trials. The Sorafenib RCC Integrated Database includes data from six clinical trials and two expanded-access studies evaluating sorafenib monotherapy in $>4600$ patients with RCC. Using this database, sorafenib tolerability and treatment patterns were analysed according to age group $(<55,55-<65,65-<75$, or $\geqslant 75$ years).

Methods: Dosing patterns, and incidence, prevalence and cumulative incidence of drug-related adverse events (DRAEs) and fatal DRAEs were assessed.

Results: Overall, 4684 patients were evaluable ( $<55$ years, $n=1126 ; 55-<65, n=1579 ; 65-<75, n=1382 ; \geqslant 75, n=559$ ). Treatment patterns were generally similar across subgroups, although sorafenib treatment duration was $\sim 30 \%$ shorter in the $\geqslant 75$-years subgroup. There were no substantial differences in any-grade DRAEs with sorafenib between subgroups. Drug-related adverse events and dose modifications due to DRAEs tended to occur in months 0-3 and declined thereafter; there was no evidence of cumulative toxicity. Fatal DRAEs were rare (0.7\% overall; $95 \%$ confidence interval, $0.5-1.0 \%)$.

Conclusion: Sorafenib was well tolerated regardless of age in a heterogeneous population of RCC patients.

The incidence of cancer and cancer-related mortality increases with age (Altekruse et al, 2011). For renal cell carcinoma (RCC), median age at diagnosis is $\sim 64$ years, with $>25 \%$ of patients aged $>75$ years (based on data for the United States (Altekruse et al, 2011)). Outcomes appear to be worse in older patients; mortality related to RCC was seven-fold higher in nephrectomized patients aged $\geqslant 75$ years $v s$ those aged $50-75$ years (Karakiewicz et al, 2008). Additionally, overall survival in RCC patients correlates negatively with the severity and number of comorbidities (Berger et al, 2008); comorbidity prevalence increases with age (Coebergh et al, 1999). Despite these observations, older patients are generally underrepresented in clinical trials (Lewis et al, 2003; Surbone, 2011). A major reason for this seems to be strict exclusion criteria based on organ-system abnormalities and functional status limitations (Lewis et al, 2003). The advent of targeted therapies has revolutionized RCC treatment, but pivotal registration trials have tended to enrol small proportions of patients aged $>65$ years (Escudier et al,

${ }^{\star}$ Correspondence: Dr G Procopio, E-mail: Giuseppe.Procopio@istitutotumori.mi.it.

Received 20 July 2012; revised 8 November 2012; accepted 10 November 2012; published online 15 January 2013 
2007a,b; Hudes et al, 2007; Motzer et al, 2007, 2008; Rini et al, 2008, 2011; Sternberg et al, 2010). The consequence is a lack of evidence-based recommendations for the treatment of elderly patients with RCC.

Sorafenib is an antiangiogenic, antiproliferative vascular endothelial growth factor receptor tyrosine kinase inhibitor (VEGFR-TKI) first approved for treatment of advanced RCC (Escudier et al, 2007a, 2009a; Stadler et al, 2010; Beck et al, 2011). Age subgroup analyses suggest that sorafenib is well tolerated and effective across age groups, but the proportions of elderly patients have tended to be small, and not reflective of real-world patient populations (Eisen et al, 2008b; Bukowski et al, 2010; Stadler et al, 2010; Beck et al, 2011; Procopio, 2011). The Sorafenib-RCC (SorRCC) Integrated Database includes safety data from $>4600$ patients enrolled in eight company-sponsored sorafenib monotherapy clinical studies. The large number of patients in the database, $>40 \%$ of whom are $\geqslant 65$ years old, allowed a retrospective examination of baseline demographics, treatment patterns, and sorafenib tolerability within age subsets, with a particular focus on the oldest patients ( $\geqslant 75$ years).

\section{PATIENTS AND METHODS}

Patients and database. Clinical data from patients with RCC treated with sorafenib monotherapy in company-sponsored trials were pooled into the Sor-RCC Integrated Database. Trial data were included if patients received only sorafenib monotherapy, and adverse events (AEs) were measured using National Cancer Institute Common Terminology Criteria for Adverse Events version 3.0. Eight Phase I, II, and III trials met these criteria ( $n=4684$; Supplementary Table 1$)$ : six were clinical development trials $(n=1008)$; two were part of the expanded-access programme $(n=3676)$ (Akaza et al, 2007; Escudier et al, 2007a, 2009b; Stadler et al, 2010; Beck et al, 2011; Tolcher et al, 2011). All studies have completed; some patients remain in follow-up. The present analysis includes data collected from November 2003 to January 2009.

The starting dose of sorafenib in all trials was $400 \mathrm{mg}$ twice daily. In the first-line study of sorafenib $v s$ interferon, the protocol allowed dose escalation to $600 \mathrm{mg}$ twice daily in patients with disease progression. The 44 patients who received at least one dose at this level were included in the integrated database at both 400 and $600 \mathrm{mg}$ twice daily. In all studies, the per protocol dose modification schedule, if required, was reduction to $400 \mathrm{mg}$ once daily, followed by additional dose reduction to a single $400 \mathrm{mg}$ dose every other day, if necessary.

Subgroup analyses. Analyses were conducted in patient subgroups defined by age at study entry: $<55$ years, $55-<65$ years, $65-<75$ years, and $\geqslant 75$ years. Incidence of a drug-related AE (DRAE) was defined as the number of patients with a DRAE starting or worsening during treatment, or within 7 days after treatment end, divided by the number of patients at risk. Drugrelated adverse event prevalence was defined as the total number of DRAEs in the population occurring (new or continuing) in a given time interval, divided by the number of patients at risk during that interval. Drug-related serious AEs (DRSAEs) were DRAEs that were life-threatening or that led to hospitalisation, death, persistent or significant disability, or birth defects.

Statistical analysis. Descriptive safety analyses (means, medians, ranges) and frequency tables were used to analyse baseline characteristics, incidence and prevalence of DRAEs and DRSAEs, and concurrent medications for the patients in each subpopulation.

\section{RESULTS}

Patients. The Sor-RCC Integrated Database includes individual data from 4684 patients enrolled in eight company-sponsored clinical trials and expanded-access programmes (Supplementary Table 1). Most patients (78\%) were from the expanded-access programmes and received open-label sorafenib in communitybased practice settings. Four age subgroups were defined: $<55$ years $(n=1126 ; 24 \%), 55-<65$ years $(n=1579 ; 34 \%), 65-<75$ years $(n=1382 ; 30 \%)$, and $\geqslant 75$ years $(n=559 ; 12 \%)$. Although the $\geqslant 75$-year-old subgroup was proportionally the smallest, it is the largest RCC population of advanced age to be studied to date. Patients were predominantly male, with clear-cell histology and a pattern of metastases typical for advanced RCC (i.e., lung, liver, lymph nodes, and bone) (Table 1). The proportion of patients with brain metastases $(2.1 \%)$ was low, consistent with such patients generally being excluded from clinical trials; in the expandedaccess programmes, patients with stable brain metastases were allowed. The percentage of nephrectomized patients was slightly lower in patients aged $\geqslant 75$ years $(81 \%)$ than in the younger age subgroups (range 87-90\%). The proportion of the oldest patients who had received cytokines was somewhat lower than in the other groups (36\% vs $51-59 \%$ ).

Clinical comorbidities tended to increase with age. For example, the proportion of patients aged $<55$ years with cardiovascular risk factors or diabetes mellitus was approximately half that in the other groups (Table 1). Similarly, the concomitant medications received suggested more cardiovascular comorbidities in the older age groups: use of anti-angiotensin agents, calcium-channel blockers, $\beta$-blockers, diuretics, and lipid-reducing agents in the youngest subgroup was approximately half that in the oldest patients (Supplementary Table 2).

Treatment duration. Treatment duration was similar among patients aged $<55,55-<65$, and $65-<75$ years (mean, 6.5-6.7 months; median, 4.0-4.2 months; Table 2). In the oldest patients, treatment duration (mean: 4.5 months; median: 3.1 months) was about $30 \%$ shorter than in the three younger subgroups. Sorafenib therapy continued for $\geqslant 12$ months in a notable proportion of patients in each subgroup, including older patients: $15 \%$ of patients aged $<55$ years, $16 \%$ of patients $55-<65$ years, $17 \%$ of patients $65-<75$ years, and $8 \%$ of patients $\geqslant 75$ years.

\section{Safety}

DRAE incidence. The incidence of DRAEs of any grade appeared to be constant or decreased slightly with age (Table 3). Grade 3/4 DRAE incidence increased modestly with age: $33 \%$ of the youngest patients experienced $\geqslant 1$ grade $3 / 4$ DRAE while on treatment compared with $41 \%$ of the oldest patients. The most common anygrade DRAEs were hand-foot skin reaction (HFSR), diarrhoea, rash/desquamation, alopecia, and fatigue; incidence did not differ markedly between age groups, with the possible exception of grade $3 / 4$ fatigue in the $\geqslant 75$-year-old subgroup (Table 3 ). The incidence of treatment-emergent hypertension was low and predominantly grade $1 / 2$.

$D R A E$ prevalence. Changes in the safety profile of sorafenib over time (prevalence) were examined by assessing the occurrence of any DRAE (grades 1-4) in 3-month intervals (Figure 1). The percentage of patients experiencing any DRAE was fairly constant over time, and generally showed a similar distribution across the age groups (Figure 1A). The prevalence of any grade 4 DRAE was low and never exceeded $5 \%$ in any interval. Grade 3 DRAEs occurred most frequently in months $0-3$; prevalence decreased thereafter with a concurrent trend for an increase in the prevalence of grade $1 / 2$ DRAEs. 
Table 1. Baseline characteristics by age

\begin{tabular}{|l|c|c|c|c|c|}
\hline Characteristics & $\begin{array}{c}\text { Total patient } \\
\text { population } \\
(\mathbf{N}=\mathbf{4 6 8 4})\end{array}$ & $\begin{array}{c}\text { Patients }<\mathbf{5 5} \text { years } \\
\text { of age }(\boldsymbol{n}=\mathbf{1 1 2 6})\end{array}$ & $\begin{array}{c}\text { Patients } \mathbf{5 5 -}<\mathbf{6 5} \text { years } \\
\text { of age }(\boldsymbol{n}=\mathbf{1 5 7 9})\end{array}$ & $\begin{array}{c}\text { Patients 65- }<\mathbf{7 5} \text { years } \\
\text { of age }(\boldsymbol{n}=\mathbf{1 3 8 2})\end{array}$ & $\begin{array}{c}\text { Patients } \geqslant \mathbf{7 5} \text { years } \\
\text { of age ( } \boldsymbol{n}=\mathbf{5 5 9})\end{array}$ \\
\hline Male, \% & 70.8 & 72.0 & 74.0 & 68.7 & 65.8 \\
\hline $\begin{array}{l}\text { Median age, years } \\
\text { (range) }\end{array}$ & $62(13-100)$ & $49(13-54)$ & $59(55-64)$ & $69(65-74)$ & $78(75-100)$ \\
\hline
\end{tabular}

ECOG PS, \%

\begin{tabular}{|l|r|r|r|r|r|}
\hline 0 & 21.8 & 26.1 & 23.1 & 21.4 \\
1 & 20.1 & 21.6 & 20.5 & 2.3 \\
2 & 3.8 & 5.3 & 3.5 & 15.6 \\
Missing $^{a}$ & 54.3 & 47.0 & 53.0 & 2.5 \\
& & 3.4 \\
\end{tabular}

Metastatic sites, \%

\begin{tabular}{|c|c|c|c|c|c|}
\hline Bone & 27.9 & 30.6 & 30.1 & 26.2 & 21.1 \\
\hline Brain & 2.1 & 2.8 & 2.0 & 1.8 & 1.6 \\
\hline Liver & 24.4 & 25.8 & 25.5 & 23.6 & 21.1 \\
\hline Lung & 72.4 & 74.0 & 72.2 & 72.6 & 71.6 \\
\hline Lymph nodes & 27.9 & 32.8 & 29.3 & 25.1 & 22.2 \\
\hline
\end{tabular}

Histology subtypes, \%

\begin{tabular}{|l|c|c|c|c|}
\hline Clear cell & 82.2 & 79.7 & 83.7 & 79.6 \\
$\begin{array}{l}\text { Predominantly } \\
\text { clear cell }\end{array}$ & 15.6 & 18.5 & 14.3 & 13.2 \\
Other & 0.7 & 0.9 & 0.6 & 0.8 \\
\hline
\end{tabular}

Prior treatment, \%

\begin{tabular}{|l|l|l|l|l|l|}
\hline Nephrectomy & 86.8 & 89.8 & 86.6 & 81.2 \\
Cytokine & 52.4 & 59.4 & 55.5 & 50.7 & 35.6 \\
Antineoplastic & 28.4 & 30.0 & 32.1 & 27.6 \\
agent & & & & \\
\hline
\end{tabular}

Medical history, \%

\begin{tabular}{|l|r|r|r|r|r}
\hline Hypertension $^{\text {b }}$ & 48.0 & 28.2 & 46.5 & 59.5 \\
Ischaemic coronary $_{\text {artery disorders }}$ & 4.4 & 1.9 & 3.8 & 5.9 \\
Anaemiac $^{\text {c }}$ & 10.5 & 10.6 & 10.7 & 10.3 \\
Diabetes mellitus $^{\text {High cholesterol }}$ & 15.1 & 8.7 & 15.9 & 1.1 \\
\hline
\end{tabular}

Abbreviations: ECOG PS = Eastern Cooperative Oncology Group performance status; MedDRA = Medical Dictionary for Regulatory Activities; NEC $=$ not elsewhere classified. MedDRA ${ }^{\circledR}$ is a registered trademark of the International Federation of Pharmaceutical Manufacturers and Associations (IFPMA).

a Performance status values were missing in a large number of patients because they were not captured in the expanded-access studies.

ber MedDRA terminology, vascular hypertensive disorders NEC.

c Per MedDRA terminology, anaemia NEC.

${ }^{d}$ Per MedDRA terminology, elevated cholesterol, elevated triglycerides, and hyperlipidaemias NEC.

The prevalence of the grade $3 / 4$ DRAEs that had the highest incidence was examined in more detail (Figures $1 \mathrm{~B}-\mathrm{F}$ ). Prevalence patterns for these DRAEs were broadly consistent with those for any DRAE. Grade $3 \mathrm{HFSR}$, and grade $3 / 4 \mathrm{rash} /$ desquamation and fatigue tended to occur most frequently in the first 3 months and decreased in later intervals; this pattern was observed across the age subgroups. Compared with younger patients, a slightly higher proportion of patients aged $\geqslant 75$ years exhibited grade $3 / 4$ fatigue and a lower proportion exhibited grade 3 HFSR. Hypertension prevalence at each grade was fairly equal across age groups, although there was a slight trend towards increased grade $1 / 2$ hypertension in patients aged $<55$ years. Diarrhoea prevalence followed a slightly different pattern to the other DRAEs. Grade 1/2 diarrhoea was least frequent in the first 3 months in all age groups, and tended to increase over time. Importantly, the prevalence of grade 3 diarrhoea was low throughout, and there were no instances of grade 4 diarrhoea.
DRSAE incidence and prevalence. The incidence and prevalence of DRSAEs followed a similar pattern to those for DRAEs (Supplementary Table 3). The overall incidence of DRSAEs increased somewhat with age, from $11.3 \%$ in the youngest group to $19.9 \%$ in the oldest. The incidence of any grade $3 / 4$ DRSAE was slightly higher in the oldest group (14\%) than in the younger groups $(8-11 \%)$. The most common specific DRSAEs (incidence $\geqslant 0.5 \%$ ) were hypertension, fatigue, HFSR, rash, and diarrhoea. The incidence of all grade DRSAEs exceeded $2 \%$ only for fatigue and rash, and only in the $\geqslant 75$-year-old subgroup.

The prevalence of grade $3 / 4$ DRSAEs was highest in the first 3 months of treatment, and then dropped by $50 \%$ or more later in treatment. Patients aged $\geqslant 75$ years experienced somewhat higher levels of DRSAEs in the first 6 months than patients in the other groups.

There were 34 (0.7\%; 95\% CI, 0.5-1.0\%) grade 5 DRAEs during the study; the overall incidence was broadly similar across age 
Table 2. Sorafenib treatment by age

\begin{tabular}{|c|c|c|c|c|c|}
\hline & $\begin{array}{l}\text { Total population } \\
(N=4684)\end{array}$ & $\begin{array}{l}\text { Patients }<55 \text { years } \\
\quad(n=1126)\end{array}$ & $\begin{array}{c}\text { Patients } 55-<65 \\
\text { years }(n=1579)\end{array}$ & $\begin{array}{l}\text { Patients } 65-<75 \\
\text { years }(n=1382)\end{array}$ & $\begin{array}{l}\text { Patients } \geqslant 75 \\
\text { years }(n=559)\end{array}$ \\
\hline \multicolumn{6}{|l|}{ Duration of therapy } \\
\hline $\begin{array}{l}\text { Mean, months } \\
\text { Median (range) }{ }^{\mathrm{a}} \text {, months }\end{array}$ & $\begin{array}{c}6.3 \\
3.9(0-51.2)\end{array}$ & $\begin{array}{c}6.7 \\
4.2(0-51.2)\end{array}$ & $\begin{array}{c}6.5 \\
4.0(0-47.4)\end{array}$ & $\begin{array}{c}6.6 \\
4.0(0-44.1)\end{array}$ & $\begin{array}{c}4.5 \\
3.1(0-37.5)\end{array}$ \\
\hline \multicolumn{6}{|c|}{ Per 3- or 6-month interval, $n(\%)$} \\
\hline $\begin{array}{l}<3 \text { months } \\
3-<6 \text { months } \\
6-<12 \text { months } \\
12-<18 \text { months } \\
18-<24 \text { months } \\
\geqslant 24 \text { months }\end{array}$ & $\begin{array}{c}1820(38.9) \\
1349(28.8) \\
808(17.3) \\
323(6.9) \\
224(4.8) \\
160(3.4)\end{array}$ & $\begin{array}{c}402(35.7) \\
328(29.1) \\
224(19.9) \\
75(6.7) \\
53(4.7) \\
44(3.9)\end{array}$ & $\begin{array}{c}612(38.8) \\
439(27.8) \\
275(17.4) \\
103(6.5) \\
97(6.1) \\
53(3.4)\end{array}$ & $\begin{array}{c}518(37.5) \\
400(28.9) \\
226(16.4) \\
124(9.0) \\
56(4.1) \\
58(4.2)\end{array}$ & $\begin{array}{c}265(47.7) \\
171(30.6) \\
80(14.3) \\
21(3.8) \\
17(3.0) \\
5(0.9)\end{array}$ \\
\hline \multicolumn{6}{|l|}{ Dosing } \\
\hline $\begin{array}{l}\text { Median, mg per day (range) } \\
\text { Mean (s.d.) } \\
\text { Patients receiving } \geqslant 90 \% \\
\text { planned dose, } \mathbf{n} \mathbf{n}(\%)\end{array}$ & $\begin{array}{c}792(55.2-1600) \\
676(171.2) \\
2515 / 4199(59.9)\end{array}$ & $\begin{aligned} 797 & (156-1121) \\
694 & (159.7) \\
627 / 978 & (64.1)\end{aligned}$ & $\begin{array}{r}796(55-1335) \\
688(163.0) \\
900 / 1417(63.5)\end{array}$ & $\begin{array}{c}768(73-1600) \\
660(180.0) \\
687 / 1250(55.0)\end{array}$ & $\begin{aligned} 768 & (167-1600) \\
650 & (186.6) \\
281 / 517 & (54.4)\end{aligned}$ \\
\hline
\end{tabular}

Table 3. Incidence of DRAEs occurring in $\geqslant 10 \%$ of patients by age

\begin{tabular}{|c|c|c|c|c|c|c|c|c|c|c|}
\hline \multirow[b]{2}{*}{ Grade, $\%$ of patients } & \multicolumn{2}{|c|}{$\begin{array}{l}\text { Total population } \\
\quad(N=4684)\end{array}$} & \multicolumn{2}{|c|}{$\begin{array}{c}\text { Patients }<55 \text { years } \\
\quad(n=1126)\end{array}$} & \multicolumn{2}{|c|}{$\begin{array}{l}\text { Patients } 55-<65 \\
\text { years }(n=1579)\end{array}$} & \multicolumn{2}{|c|}{$\begin{array}{l}\text { Patients } 65-<75 \\
\text { years }(n=1382)\end{array}$} & \multicolumn{2}{|c|}{$\begin{array}{l}\text { Patients } \geq 75 \text { years } \\
\quad(n=559)\end{array}$} \\
\hline & Any & $3-4$ & Any & $3-4$ & Any & $3-4$ & Any & $3-4$ & Any & $3-4$ \\
\hline Any DRAE & 82.3 & 37.6 & 79.5 & 33.3 & 83.3 & 37.5 & 84.7 & 39.6 & 81.0 & 41.4 \\
\hline Hand-foot skin reaction & 36.2 & 9.7 & 39.3 & 10.0 & 37.5 & 9.6 & 36.0 & 10.1 & 28.3 & 8.4 \\
\hline Diarrhoea & 35.4 & 4.0 & 32.2 & 3.3 & 39.7 & 4.6 & 36.8 & 4.4 & 27.0 & 2.9 \\
\hline Rash/desquamation & 30.2 & 4.3 & 30.6 & 4.1 & 30.2 & 3.6 & 30.6 & 5.0 & 29.3 & 5.0 \\
\hline Alopecia & 21.5 & $<0.1$ & 24.2 & 0.1 & 22.0 & 0 & 21.6 & 0 & 15.0 & 0.2 \\
\hline Fatigue & 24.7 & 4.8 & 21.1 & 3.8 & 23.9 & 3.6 & 26.5 & 5.5 & 30.4 & 9.0 \\
\hline Nausea & 13.7 & 1.2 & 16.3 & 1.3 & 13.4 & 1.3 & 12.5 & 0.9 & 12.0 & 1.4 \\
\hline Hypertension & 17.4 & 5.0 & 15.9 & 3.6 & 18.6 & 5.4 & 14.5 & 5.9 & 13.2 & 5.2 \\
\hline Anorexia & 14.8 & 1.4 & 13.2 & 1.2 & 13.4 & 1.2 & 16.4 & 1.7 & 18.6 & 2.0 \\
\hline Pruritus & 9.2 & 0.4 & 10.7 & 0.5 & 9.7 & 0.3 & 8.4 & 0.3 & 6.8 & 0.4 \\
\hline Oral mucositis, clinical examination & 9.6 & 0.8 & 10.4 & 0.7 & 8.9 & 1.1 & 10.1 & 0.6 & 9.3 & 0.9 \\
\hline
\end{tabular}

subgroups (0.4-1.0\%; Table 4). Most events occurred within months $0-3$ (Table 4). Grade 5 DRAEs occurring in $\geqslant 2$ patients were haemorrhage/bleeding events $(n=6$, bleeding sites differed between patients), renal failure $(n=5)$, cardiac ischaemia/infarction $(n=3)$, perforation of the colon $(n=2)$, and perforation of the small bowel $(n=2)$.

Dosing patterns. The median/mean daily dose of sorafenib was consistent across age groups. The proportion of patients receiving at least $90 \%$ of planned doses was slightly higher in patients aged $<55$ years or $55-<65$ years than in those aged $65-<75$ years or $\geqslant 75$ years (Table 2 ).

The incidence of dose modifications (reductions or interruptions) due to any $\mathrm{AE}$ was also generally similar between age groups. In each age group, most patients $(>50 \%)$ did not require any dose modification owing to AEs; the proportion of patients requiring two or more dose modifications was low (20-23\%; Figure 2A). Most patients $(>98 \%)$ initiated treatment at the standard dose (400 mg twice daily; Figure 2B). Compared with younger patients, there was a trend for older patients to be dose interrupted or dose reduced to $400 \mathrm{mg}$ once daily due to AEs (Figure $2 \mathrm{~B}$ ). For patients whose dose was reduced or interrupted, there was also a trend for older patients not to be re-escalated to full dose, compared with younger patients, with a concurrent trend for older patients to remain at $400 \mathrm{mg}$ once daily (Figure 2B). The prevalence of dose modifications owing to DRAEs (Supplementary Figure 1) was generally consistent with the prevalence data for DRAEs (Figure 1). In the oldest patients, the prevalence of dose modifications owing to DRAEs tended to be higher than in younger patients; however, the relatively small number of patients in the oldest group after month 12 precludes meaningful conclusions. 

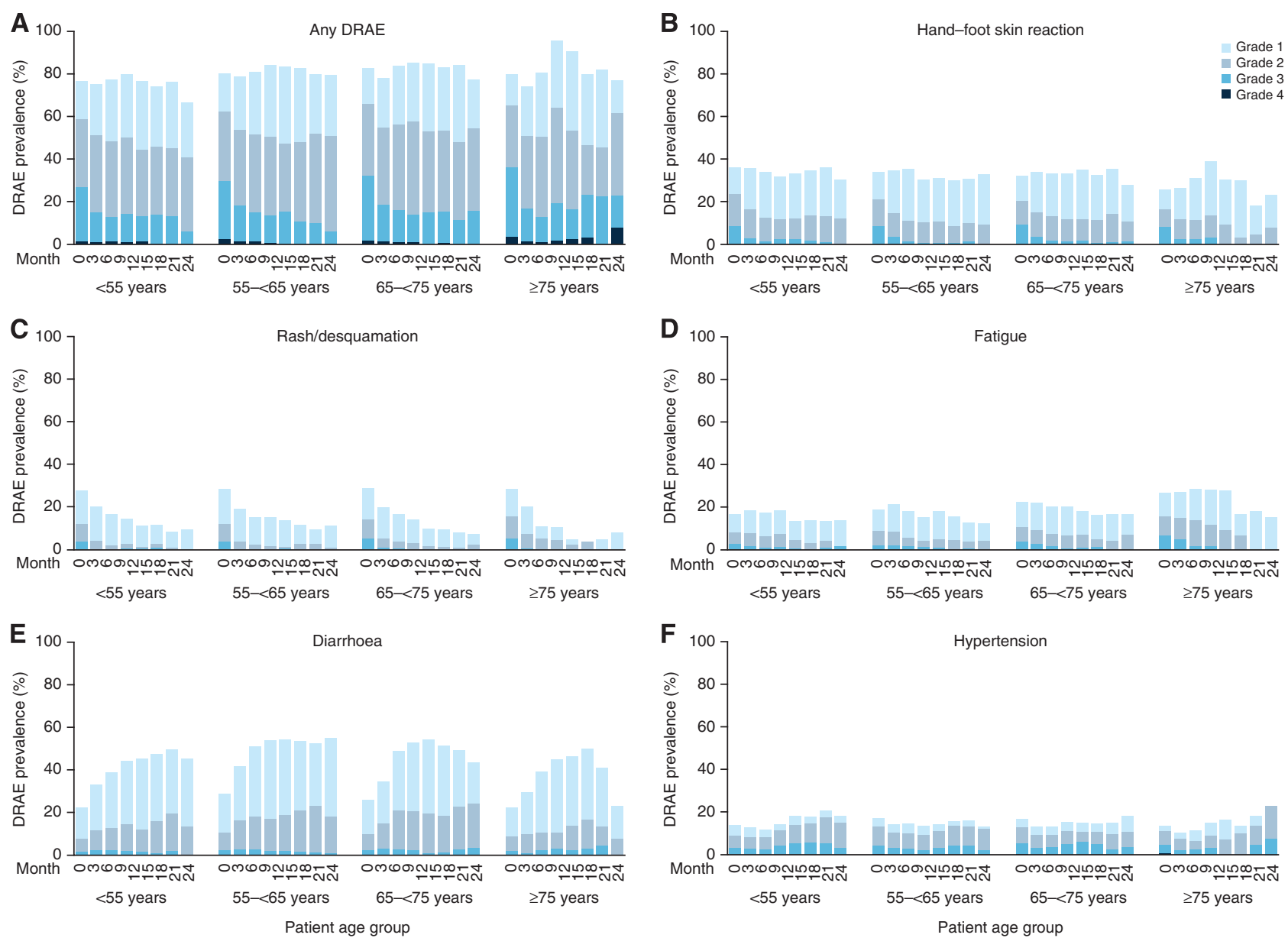

Figure 1. Prevalence of selected DRAEs by grade and time (3-month intervals over 24 months). (A) Any DRAE; (B-F) DRAEs with the highest grade 3/4 incidence: (B) HFSR, (C) rash/desquamation, (D) fatigue, (E) diarrhoea, and (F) hypertension. For the selected DRAEs, the prevalence of grade 4 DRAEs was $\leqslant 0.4 \%$ at any time point and in any age subgroup. No patient had grade 4 HFSR or diarrhoea. No patient had grade 4 fatigue, hypertension or rash/desquamation after months $0-3$, except fatigue in one patient aged $55-<65$ years and two patients aged $65-<75$ years, during months 3-6; and in one patient aged $65-<75$ years, during months 6-9. DRAE = drug-related adverse event; HFSR = hand-foot skin reaction.

Table 4. Incidence and prevalence of grade 5 (fatal) DRAEs

\begin{tabular}{|l|c|c|c|c|c|}
\hline $\begin{array}{l}\text { Interval, } \\
\text { months }\end{array}$ & $\begin{array}{c}\text { Total population } \\
(N=4684)\end{array}$ & $\begin{array}{c}\text { Patients }<55 \text { years } \\
(n=1126)\end{array}$ & $\begin{array}{c}\text { Patients } 55-<65 \text { years } \\
(n=1579)\end{array}$ & $\begin{array}{c}\text { Patients } 65-<75 \text { years } \\
(n=1382)\end{array}$ & $\begin{array}{c}\text { Patients } \geqslant 75 \text { years } \\
(n=559)\end{array}$ \\
\hline
\end{tabular}

Grade 5 DRAEs at any time, $n / n(\% ; 95 \% \mathrm{Cl})^{a}$

\begin{tabular}{|c|c|c|c|c|c|}
\hline & $34 / 4684(0.7 ; 0.5-1.0)$ & $7 / 1126(0.6 ; 0.3-1.3)$ & $11 / 1579(0.7 ; 0.3-1.2)$ & $14 / 1382(1.0 ; 0.6-1.7)$ & $2 / 559(0.4 ; 0.04-1.3)$ \\
\hline \multicolumn{6}{|c|}{ Grade 5 DRAEs per 3-month interval, $n / n(\%)$} \\
\hline$<3$ & $20 / 4684(0.4)$ & $2 / 1126(0.2)$ & 7/1579 (0.4) & 9/1382 (0.7) & $2 / 559(0.4)$ \\
\hline $3-6$ & $5 / 2864(0.2)$ & $2 / 724(0.3)$ & $1 / 967(0.1)$ & $2 / 864(0.2)$ & 0/294 (0) \\
\hline $6-9$ & $2 / 1515(0.1)$ & $1 / 396(0.3)$ & $1 / 528(0.2)$ & $0 / 464(0)$ & $0 / 123(0)$ \\
\hline $9-12$ & $3 / 993(0.3)$ & $1 / 254(0.4)$ & $1 / 349(0.3)$ & $1 / 321(0.3)$ & $0 / 67(0)$ \\
\hline $12-15$ & $2 / 707(0.3)$ & $1 / 172(0.6)$ & $0 / 253(0)$ & $1 / 238(0.4)$ & $0 / 43(0)$ \\
\hline $15-18$ & $0 / 507(0)$ & $0 / 124(0)$ & $0 / 191(0)$ & $0 / 161(0)$ & $0 / 30(0)$ \\
\hline $18-21$ & $0 / 384(0)$ & 0/97 (0) & $0 / 150(0)$ & $0 / 114(0)$ & $0 / 22(0)$ \\
\hline $21-24$ & $0 / 260(0)$ & $0 / 66(0)$ & $0 / 98(0)$ & $0 / 83(0)$ & $0 / 13(0)$ \\
\hline
\end{tabular}

Abbreviations: $\mathrm{Cl}=$ confidence interval; DRAEs = drug-related adverse events.

${ }^{a}$ Number of fatal DRAEs occurring during the entire observation period.

National Cancer Institute Common Terminology Criteria for Adverse Events (CTCAE) version 3 and worst CTCAE grade. 

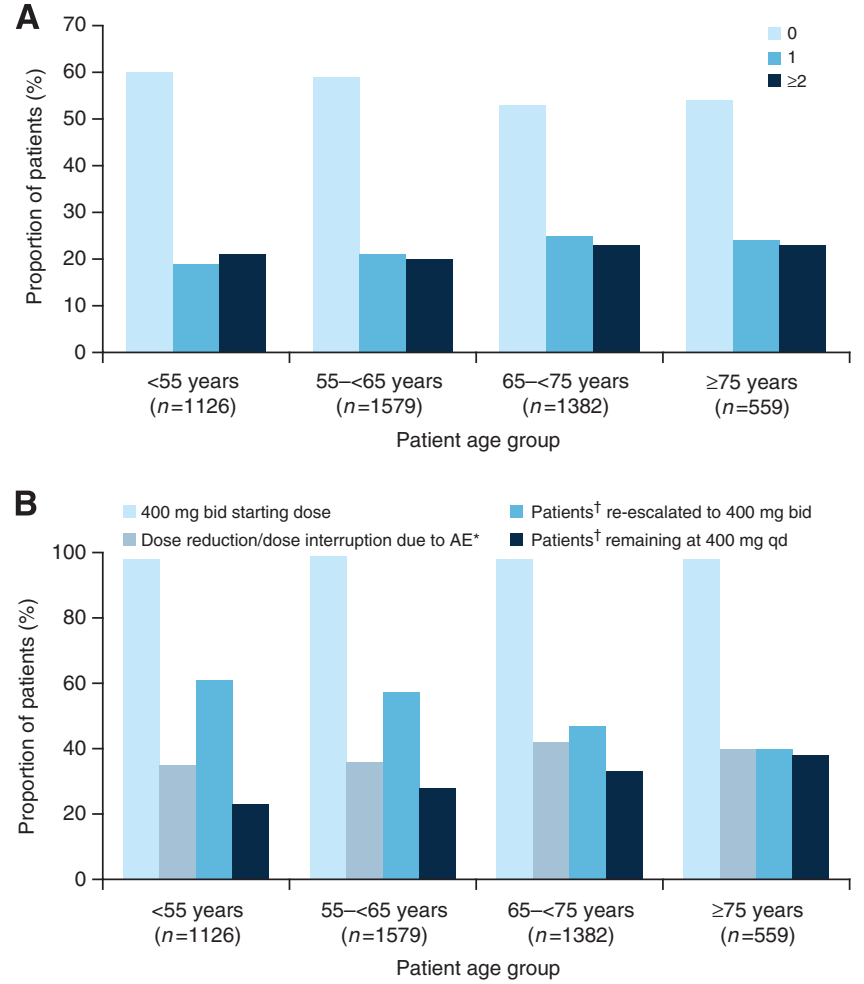

Figure 2. Dosing patterns for patients experiencing AEs.

(A) Proportion of patients requiring 0,1 , or $\geqslant 2$ dose reductions or interruptions due to an $\mathrm{AE}$; (B) Proportion of patients initiated at $400 \mathrm{mg}$ bid and dose reduced or dose interrupted, followed by re-escalation, or continuation at the lower dose of $400 \mathrm{mg}$ once daily. *Of those patients who received sorafenib $400 \mathrm{mg}$ bid as the starting dose. ${ }^{\dagger}$ Of those patients with a dose reduction/dose interruption from $400 \mathrm{mg}$ bid. $\mathrm{AE}=$ adverse event; bid = twice daily; $\mathrm{qd}=$ once daily.

\section{DISCUSSION}

The Sor-RCC Integrated Database is a valuable resource for assessing tolerability and treatment patterns in $>4600$ patients with RCC who received sorafenib in clinical trials or expandedaccess programmes. Both incidence and prevalence of AEs can be ascertained from the database. The prevalence of AEs at specific points in time gives an indication of whether the pattern of AEs changes with time - for example, do new AEs appear in patients receiving long-term therapy? Additionally, the database includes a large number of elderly patients, with 1382 (30\% of the database) aged $65-<75$ years at baseline and 559 patients aged $\geqslant 75$ years. Although the latter group is only $12 \%$ of the database, and this relatively small proportion is undoubtedly a limitation, it nevertheless represents (to our knowledge) the largest group of RCC patients aged $\geqslant 75$ years whose treatment patterns have been systematically studied. This is important because patients aged $>65$ years (and, even more so, those aged $\geqslant 75$ ) are generally underrepresented in clinical trials (Lewis et al, 2003; Surbone, 2011). We therefore used the Sor-RCC Integrated Database to evaluate dosing patterns, and the incidence and prevalence of DRAEs in patients with RCC receiving sorafenib treatment, including subanalyses according to age.

The Sor-RCC Integrated Database included patients from randomized clinical trials, which have strict inclusion criteria, but $78 \%$ were from expanded-access programmes. Inclusion criteria for such programmes are less strict than those for RCTs; however, patients are prospectively accrued according to set protocols. This raises the possibility that patients with poorer performance status and major comorbidities will still be underrepresented relative to unselected patients. However, the demographics and baseline characteristics of our population were broadly consistent with those in the general population with RCC. The ratio of men:women was $\sim 2: 1$ and median age was 62 years, consistent with cancer statistics for the United States (2004-2007; Altekruse et al, 2011). In addition, a medical history of cardiovascular comorbidities was more frequent in older patients than younger patient in our database, consistent with previous observations (Coebergh et al, 1999). Together, these results suggest that the patient population in our database is generally representative of patients in clinical practice, including those with comorbidities.

Our analyses were not controlled for prognostic risk group, and the possible confounding effects of this variable cannot be excluded. However, while acknowledging this possible limitation, we conclude that sorafenib was generally well tolerated regardless of age. There were no substantial differences in the incidence of specific any-grade or grade $3 / 4$ DRAEs between age groups. The higher frequency of comorbidities in older patients than in younger patients did not appear to result in more DRAEs with sorafenib. For example, the incidence and severity of hypertension as a DRAE was not substantially different between age subgroups despite the numerically higher incidence of comorbid hypertension in older patients than in younger patients. Notably, sorafenib was generally well tolerated regardless of presence or absence of baseline cardiovascular comorbidities in a subgroup analysis of the EUARCCS expanded-access study (Eisen et al, 2008a).

Analysis of DRAE prevalence did not indicate cumulative toxicity with long-term sorafenib therapy. Across age subgroups, the prevalence of grade 3/4 DRAEs tended to decrease over the course of therapy, with a concurrent trend for increasing prevalence of grade 1/2 DRAEs, suggesting a shift to less-severe toxicity with continued sorafenib treatment. This could reflect successful management of DRAEs during long-term therapy; it has been suggested that effective monitoring and management of AEs is key to optimising sorafenib duration of therapy (Hutson et al, 2010; Edmonds et al, 2012).

Fatal DRAEs were rare across age subgroups in this analysis. This is important, as two meta-analyses previously concluded that VEGFR-TKIs were associated with an increased risk of fatal AEs compared with placebo/control (Schutz et al, 2012; Sivendran et al, 2012). Schutz and coworkers reported an overall incidence of fatal DRAEs of $1.5 \%$ with sunitinib, sorafenib or pazopanib, and suggested that their meta-analysis may have actually underestimated the incidence of fatal AEs associated with these agents, as patients in clinical trials tend to have better performance status than those in clinical practice. Sivendran and coworkers reported a fatal $\mathrm{AE}$ rate of $3.68 \%$ for patients receiving sunitinib, sorafenib or pazopanib for RCC compared with $2.27 \%$ for patients receiving control. A subgroup analysis of the three sorafenib studies evaluated (two in RCC and one in HCC) suggested a higher rate of fatal events for sorafenib (3.21\%) compared with control $(2.15 \%)$. However, for each meta-analysis, some important caveats should be considered. The meta-analysis from Schutz and coworkers included patients with various malignancies, and included both monotherapy and combination therapy trials; the incidence of fatal DRAEs in patients with a particular malignancy receiving a specific therapy therefore cannot be ascertained from the meta-analysis. The report from Sivendran and coworkers considered fatal AEs regardless of causality (not specifically DRAEs). In addition, the authors acknowledge that their findings with regard to sorafenib should be considered only as hypothesis generating, as the total number of events involved was relatively few. Importantly, the Sor-RCC Integrated Database includes data for a large number of patients $(N=4684)$ from monotherapy 
studies in RCC only, and is thus particularly well suited for evaluating the incidence of fatal DRAEs associated with sorafenib treatment in RCC patients; our analysis in this large patient population suggests that the incidence of fatal DRAEs with sorafenib is approximately half that reported for VEGFR-TKIs by Schutz and coworkers.

There were indications in our study that patients aged $\geqslant 75$ years were managed more conservatively than younger patients. The oldest patients were less likely to have previously received nephrectomy and/or cytokines, were treated for slightly shorter time periods, and were more likely to have received dose modifications and/or discontinuations due to DRAEs, particularly early in treatment. These patients were also more likely to remain on a lower dose after dose reduction, rather than be re-escalated to the full dose. A limitation of our data is that performance status is missing for most patients, so it is unclear whether these treatment differences reflect greater frailty in older patients or complications arising from the higher prevalence of comorbidities. Importantly, an appreciable proportion of the oldest patients $(8 \%)$ were able to receive sorafenib therapy for $\geqslant 12$ months.

\section{CONCLUSIONS}

In this large, pooled analysis of a diverse population of patients with RCC, sorafenib was well tolerated across all age subgroups, including those $\geqslant 75$ years. These observations suggest that sorafenib is a well tolerated and effective option for the treatment of advanced RCC, regardless of patient age.

\section{ACKNOWLEDGEMENTS}

We are grateful to 7.4 Limited for providing editorial support, with unrestricted financial support from Bayer HealthCare Pharmaceuticals.

\section{CONFLICT OF INTEREST}

Giuseppe Procopio has received consulting fees and had an advisory role from Bayer HealthCare Pharmaceuticals, Pfizer and GSK. Joaquim Bellmunt has received consulting and lecture fees from Bayer HealthCare Pharmaceuticals, Novartis and Roche. Janice Dutcher has had an advisory role with Pfizer, Prometheus and Genentech; has served on speakers' bureaux for Pfizer, Prometheus, Bayer HealthCare Pharmaceuticals/Onyx, Novartis and GSK; and has received research funds from Prometheus, Exelixis, and BMS. Sergio Bracarda has served on advisory boards for Pfizer, GSK, Novartis, Bayer HealthCare Pharmaceuticals, Boehringer Ingelheim, Sanofi-Aventis and Janssen-Cilag, and has received lecture fees from Pfizer, Novartis and Sanofi-Aventis. Jennifer Knox has received research support from Bayer HealthCare Pharmaceuticals. Andreas Brueckner and Istvan Molnarg are employees of Bayer HealthCare Pharmaceuticals. Bernard Escudier has served as a consultant for Bayer HealthCare Pharmaceuticals, GSK, Pfizer, Novartis, Roche and AVEO. Thomas Hutson has received research support from, and served as a consultant and on speakers' bureaux for, Bayer HealthCare Pharmaceuticals, GSK, Pfizer, AVEO, Novartis, Genentech and OrthoBiotech.

\section{REFERENCES}

Akaza H, Tsukamoto T, Murai M, Nakajima K, Naito S (2007) Phase II study to investigate the efficacy, safety, and pharmacokinetics of sorafenib in
Japanese patients with advanced renal cell carcinoma. Jpn J Clin Oncol 37: $755-762$.

Altekruse SF, Kosary CL, Krapcho M, Neyman N, Aminou R, Waldron W, Ruhl J, Howlader N, Tatalovich Z, Cho H, Mariotto A, Eisner MP, Lewis DR, Cronin K, Chen HS, Feuer EJ, Stinchcomb DG, Edwards BK (eds) (2011) SEER Cancer Statistics Review, 1975-2007. National Cancer Institute: Bethesda, MD. http://seer.cancer.gov/csr/1975_2007/index.html (Accessed 18 Aug. 2011).

Beck J, Procopio G, Bajetta E, Keilholz U, Negrier S, Szczylik C, Bokemeyer C, Bracarda S, Richel DJ, Staehler M, Strauss UP, Mersmann S, Burock K, Escudier B (2011) Final results of the European Advanced Renal Cell Carcinoma Sorafenib (EU-ARCCS) expanded-access study: a large open-label study in diverse community settings. Ann Oncol 22: 1812-1823.

Berger DA, Megwalu II, Vlahiotis A, Radwan MH, Serrano MF, Humphrey PA, Piccirillo JF, Kibel AS (2008) Impact of comorbidity on overall survival in patients surgically treated for renal cell carcinoma. Urology 72 : 359-363.

Bukowski RM, Stadler WM, McDermott DF, Dutcher JP, Knox JJ, Miller Jr. WH, Hainsworth JD, Henderson CA, Hajdenberg J, Kindwall-Keller TL, Ernstoff MS, Drabkin HA, Curti BD, Chu L, Ryan CW, Hotte SJ, Xia C, Cupit L, Figlin RA (2010) Safety and efficacy of sorafenib in elderly patients treated in the North American advanced renal cell carcinoma sorafenib expanded access program. Oncology 78: 340-347.

Coebergh JW, Janssen-Heijnen ML, Post PN, Razenberg PP (1999) Serious co-morbidity among unselected cancer patients newly diagnosed in the southeastern part of The Netherlands in 1993-1996. J Clin Epidemiol 52: $1131-1136$.

Edmonds K, Hull D, Spencer-Shaw A, Koldenhof J, Chrysou M, Boers-Doets C, Molassiotis A (2012) Strategies for assessing and managing the adverse events of sorafenib and other targeted therapies in the treatment of renal cell and hepatocellular carcinoma: recommendations from a European nursing task group. Eur J Oncol Nurs 16: 172-184.

Eisen T, Beck J, Procopio G, Negrier S, Keilholz U, von der Maase H, Strauss UP, Burock K, Mersmann S, Escudier B (2008a) Large open-label, noncomparative phase III study of sorafenib in European patients with advanced RCC (EU-ARCCS) - subgroup analysis of patients with and without baseline clinical cardiovascular disease (CCD). Ann Oncol 19: viii194 (abstract 602P).

Eisen T, Oudard S, Szczylik C, Gravis G, Heinzer H, Middleton R, Cihon F, Anderson S, Shah S, Bukowski R, Escudier B (2008b) Sorafenib for older patients with renal cell carcinoma: subset analysis from a randomized trial. J Natl Cancer Inst 100: 1454-1463.

Escudier B, Eisen T, Stadler WM, Szczylik C, Oudard S, Siebels M, Negrier S, Chevreau C, Solska E, Desai AA, Rolland F, Demkow T, Hutson TE, Gore M, Freeman S, Schwartz B, Shan M, Simantov R, Bukowski RM (2007a) Sorafenib in advanced clear-cell renal-cell carcinoma. $N$ Engl J Med 356: $125-134$.

Escudier B, Eisen T, Stadler WM, Szczylik C, Oudard S, Staehler M, Negrier S, Chevreau C, Desai AA, Rolland F, Demkow T, Hutson TE, Gore M, Anderson S, Hofilena G, Shan M, Pena C, Lathia C, Bukowski RM (2009a) Sorafenib for treatment of renal cell carcinoma: final efficacy and safety results of the phase III treatment approaches in renal cancer global evaluation trial. J Clin Oncol 27: 3312-3318.

Escudier B, Pluzanska A, Koralewski P, Ravaud A, Bracarda S, Szczylik C, Chevreau C, Filipek M, Melichar B, Bajetta E, Gorbunova V, Bay JO, Bodrogi I, Jagiello-Gruszfeld A, Moore N (2007b) Bevacizumab plus interferon alfa-2a for treatment of metastatic renal cell carcinoma: a randomised, double-blind phase III trial. Lancet 370: 2103-2111.

Escudier B, Szczylik C, Hutson TE, Demkow T, Staehler M, Rolland F, Negrier S, Laferriere N, Scheuring UJ, Cella D, Shah S, Bukowski RM (2009b) Randomized phase II trial of first-line treatment with sorafenib versus interferon alfa-2a in patients with metastatic renal cell carcinoma. J Clin Oncol 27: 1280-1289.

Hudes G, Carducci M, Tomczak P, Dutcher J, Figlin R, Kapoor A, Staroslawska E, Sosman J, McDermott D, Bodrogi I, Kovacevic Z, Lesovoy V, Schmidt-Wolf IG, Barbarash O, Gokmen E, O'Toole T, Lustgarten S, Moore L, Motzer RJ (2007) Temsirolimus, interferon alfa, or both for advanced renal-cell carcinoma. $N$ Engl J Med 356: 2271-2281. Hutson TE, Bellmunt J, Porta C, Szczylik C, Staehler M, Nadel A, Anderson S, Bukowski R, Eisen T, Escudier B (2010) Long-term safety of sorafenib in advanced renal cell carcinoma: follow-up of patients from phase III TARGET. Eur J Cancer 46: 2432-2440. 
Karakiewicz PI, Jeldres C, Suardi N, Hutterer GC, Perrotte P, Capitanio U, Ficarra V, Cindolo L, De La TA, Tostain J, Mulders PF, Salomon L, Zigeuner R, Schips L, Chautard D, Valeri A, Lechevallier E, Descots JL, Lang H, Mejean A, Verhoest G, Patard JJ (2008) Age at diagnosis is a determinant factor of renal cell carcinoma-specific survival in patients treated with nephrectomy. Can Urol Assoc J 2: 610-617.

Lewis JH, Kilgore ML, Goldman DP, Trimble EL, Kaplan R, Montello MJ, Housman MG, Escarce JJ (2003) Participation of patients 65 years of age or older in cancer clinical trials. J Clin Oncol 21: 1383-1389.

Motzer RJ, Escudier B, Oudard S, Hutson TE, Porta C, Bracarda S, Grunwald V, Thompson JA, Figlin RA, Hollaender N, Urbanowitz G, Berg WJ, Kay A, Lebwohl D, Ravaud A (2008) Efficacy of everolimus in advanced renal cell carcinoma: a double-blind, randomised, placebo-controlled phase III trial. Lancet 372: 449-456.

Motzer RJ, Hutson TE, Tomczak P, Michaelson MD, Bukowski RM, Rixe O, Oudard S, Negrier S, Szczylik C, Kim ST, Chen I, Bycott PW, Baum CM, Figlin RA (2007) Sunitinib versus interferon alfa in metastatic renal-cell carcinoma. $N$ Engl J Med 356: 115-124.

Procopio G (2011) Role of sorafenib in renal cell carcinoma: focus on elderly patients. Expert Rev Anticancer Ther 11: 1689-1692.

Rini BI, Escudier B, Tomczak P, Kaprin A, Szczylik C, Hutson TE, Michaelson MD, Gorbunova VA, Gore ME, Rusakov IG, Negrier S, Ou YC, Castellano D, Lim HY, Uemura H, Tarazi J, Cella D, Chen C, Rosbrook B, Kim S, Motzer RJ (2011) Comparative effectiveness of axitinib versus sorafenib in advanced renal cell carcinoma (AXIS): a randomised phase 3 trial. Lancet 378: 1931-1939.

Rini BI, Halabi S, Rosenberg JE, Stadler WM, Vaena DA, Ou SS, Archer L, Atkins JN, Picus J, Czaykowski P, Dutcher J, Small EJ (2008) Bevacizumab plus interferon alfa compared with interferon alfa monotherapy in patients with metastatic renal cell carcinoma: CALGB 90206. J Clin Oncol 26: $5422-5428$
Schutz FA, Je Y, Richards CJ, Choueiri TK (2012) Meta-analysis of randomized controlled trials for the incidence and risk of treatmentrelated mortality in patients with cancer treated with vascular endothelial growth factor tyrosine kinase inhibitors. J Clin Oncol 30: 871-877.

Sivendran S, Liu Z, Portas Jr. LJ, Yu M, Hahn N, Sonpavde G, Oh WK, Galsky MD (2012) Treatment-related mortality with vascular endothelial growth factor receptor tyrosine kinase inhibitor therapy in patients with advanced solid tumors: a meta-analysis. Cancer Treat Rev 38: 919-925.

Stadler WM, Figlin RA, McDermott DF, Dutcher JP, Knox JJ, Miller Jr. WH, Hainsworth JD, Henderson CA, George JR, Hajdenberg J, Kindwall-Keller TL, Ernstoff MS, Drabkin HA, Curti BD, Chu L, Ryan CW, Hotte SJ, Xia C, Cupit L, Bukowski RM (2010) Safety and efficacy results of the advanced renal cell carcinoma sorafenib expanded access program in North America. Cancer 116: 1272-1280.

Sternberg CN, Szczylik C, Lee E, Salman PV, Mardiak J, Davis ID, Pandite L, Chen M, McCann L, Hawkins R (2010) A randomized, double-blind phase III study of pazopanib in treatment-naive and cytokine-pretreated patients with advanced renal cell carcinoma (RCC). J Clin Oncol 28: 1061-1068.

Surbone A (2011) Ethical considerations in conducting clinical trials for elderly cancer patients. Aging Health 4: 253-260.

Tolcher AW, Appleman LJ, Shapiro GI, Mita AC, Cihon F, Mazzu A, Sundaresan PR (2011) A phase I open-label study evaluating the cardiovascular safety of sorafenib in patients with advanced cancer. Cancer Chemother Pharmacol 67: 751-764.

This work is licensed under the Creative Commons Attribution-NonCommercial-Share Alike 3.0 Unported License. To view a copy of this license, visit http://creativecommons. org/licenses/by-nc-sa/3.0/

Supplementary Information accompanies this paper on British Journal of Cancer website (http://www.nature.com/bjc) 